\title{
LAS MÁSCARAS DE PESSOA
}

\author{
Agustín Faro Forteza \\ UNED
}

\section{Pessoa y sus heterónimos}

Los heterónimos son las prolongaciones literarias de Fernando Pessoa. Mediante cllos, más que desdoblarse a sí mismo, puede componer una obra total, una obra que, aunque fruto de una única mano, parece una suma de obras independientes. Personalmente creo que Pessoa crea los heterónimos para conformarse como el escritor absoluto, el escritor de escritores que es capaz de ser múltiple a partir de la unicidad. Él mismo dirá: «Hoy ya no tengo personalidad: cuanto en mí pueda haber de humano lo he repartido entre los diversos autores de cuya obra he sido ejecutor. Hoy soy el punto de reunión de una pequeña humanidad sólo mía» (apud Molina 1999: 11). Para ello crea cuatro personajes, me refiero a los grandes heterónimos, y a cada uno de ellos no sólo le inventa una biografía, sino también una poética, un modo personal de concebir el universo para luego reflejarlo en los textos. Con mucho acierto Crespo señala que son las poesías las que crean a los poetas (heterónimos): «son sus poesías quienes los crean, los van formando y caracterizando, y no ellos quienes crean sus poemas desde una existencia, un carácter y un temperamento anterior a ellos» (Crespo 1988: 128). El propio Pessoa consideraba que «estas individualidades deben ser consideradas como distintas del autor» y, consciente de la autonomía de los heterónimos, compara su psicología de seres semi-humanos y afirma: "Caeiro no tiene más ética que la simplicidad. Reis posee una ética pagana medio epicureísta, medio estoica, pero muy definida, que proporciona a su poesía una elevación que cl propio Caeiro [...] no logra alcanzar. Álvaro de Campos no tiene sin sombra de ética, es amoral, aunque no positivamente inmoral, pues es evidente, según su teoría, que ama naturalmente las sensaciones fuertes en mayor medida que las débiles; y las sensaciones son, cuando menos, egoístas, y en muchas ocasiones las sensaciones de la crueldad y la lujuria» (Llardent 1894: 


\section{LAS MÁSCARAS DE PESSOA}

34) ${ }^{1}$. De modo que puede afirmarse que Campos cree en la sensación, Reis en la forma, Pessoa en los símbolos y Caeiro no cree en nada, existe, es el maestro, hasta del propio Pessoa, es «el hombre reconciliado con la naturaleza» ${ }^{2}$. Y también el poeta los describe como génesis de su propio pensamiento: «Puse en Caeiro todo mi poder de despersonalización dramática, puse en Ricardo Reis toda mi disciplina mental revestida de la música que le es propia, puse en Álvaro de Campos toda la emoción que no debo ni a mí ni a la vida» (Pessoa apud Molina 1999: 12). Y concluye: «Sea como sea, el origen mental de mis heterónimos está en mi tendencia orgánica y constante a la despersonalización y a la simulación. Estos fenómenos [...] estallan hacia dentro y los vivo a solas conmigo» (apud Molina 1999: 12) ${ }^{3}$. $\Lambda$ partir de estas definiciones, se tratará de reconstruir las bases esenciales de la poética de estos "semi-autores".

\section{1. Alberto Caeiro}

«En el panorama de la literatura portuguesa de principios de siglo, la poesía de Caciro representa la ruptura con el saudosismo que Pessoa no se atrevía a consumar» (Crespo 1988: 127). Esta afirmación puede ayudar a comprender por qué Caciro se constituye como el maestro de los otros heterónimos mayores. Rompe con la tradición y crea, a su vez, tradición. El postulado principal de la poesía de Caciro, que luego vamos a desarrollar, es el siguiente: el mundo existe porque me lo dicen los sentidos, sólo existe lo que se ve, no lo que se deduce de forma abstracta ${ }^{4}$. Esta afirmación tan común y generalmente compartida me ha de servir como punto de partida para explicar el universo caciriano a partir de dos hipótesis relacionadas con el ser de las cosas. La primera hipótesis que sostengo es que "las cosas son porque están en su tiempo", y la segunda es una paráfrasis de la idea básica del universo filosófico de Parménides de Elea: "Lo que es, es y no puede no ser". Nada podría ni puede habitar un momento diferente que lo capta nuestra percepción. La parte del mundo exterior que no percibimos por los sentidos es nada, puesto que su existencia es ajena a nosotros. Es un conocimiento metafísico, sabemos, o queremos creer que existe, porque nuestra percepción nos ha informado de su realidad, pero desde el momento en que no existe como presente sensitivo, la "cosa" es un recuerdo que sólo habita la región de la memoria. Por otro lado, la afirmación de Parménides aún es más obvia y transparente en la poesía de Caeiro. El maestro sólo describe lo que ve, sin preguntarse ni buscar más respuestas que el objeto que en sí mismo se ofrece a los sentidos, muy en particular, a la vista. Puedo, pues, negar aquello que habita en el conocimiento, pero no puedo negar la realidad que palpan los sentidos, lo que se muestra ante el ojo y es susceptible de ser tocado u olido, en suma, la realidad empírica de los "objetos", de las "cosas", las justifica en sí mismas. Y eso es lo que hace Caeiro, dar fe y testimonio de la realidad en cuanto es. Caciro le da la vuclta a Descartes y convierte el "Cogito, ergo sum", una teoría del universo a partir de una afirmación lógica basada en la racionalidad, en "Sicnto, luego existo". Idea que también comparte Cuervo Hewitt: "ya que si el filósofo francés establece "Pienso, luego existo", Caeiro construye su mundo a partir de lo contrario, la sensación". (Cuervo 1990: 465), y utiliza los siguientes versos para demostrar su afirmación: «Sei que sou real também [...] Digo de mim, 'sou eu'» (Viqueira 1997: 312/314).

1.- El texto aparece en el libro que prepara Llardent y es, en realidad, una autodescripción que Pessoa hiciera de sí mismo bajo el título: Breve introducción a Fernando Pessoa por sí mismo.

2.- Cuervo justifica su magisterio: «A poesia caciriana que persegue o momento inicial das coisas, antes das idéias, antes de ter começado a fiç̧ão, muito imaginativa às vezes das crenças ocidentais, é incarnação alegórica do começo, e por isso mestren (Cuervo 1990: 473).

3.- Arribat establece una diferencia entre los tres heterónimos atendiendo al tratamiento y a la comprensión que realizan del tiempo: «Entre o tempo falsamente eterno do pastor Caeiro e o tempo nocturno de Álvaro de Campos $[\ldots]$ existe o tempo intemporal, o tempo da pura ficção horaciana das Odes de Ricardo Reis $[\ldots]$ três metáforas da temporalidade, três maneiras de fingir sublimemente, que o enigma podia ser resolvido» (Arribat 1990: 164).

4.- Poemas inconjumtos es la colección donde mejor puede apreciarse esa sublimación de la mírada como objeto de conocimiento del mundo que nos rodea. 


\section{AGUSTÍN FARO FORTEZA}

Pero ¿quién es Caeiro?, ¿qué lugar ocupa entre los heterónimos? La segunda respuesta casi aparece dada en el párrafo inicial. Para la primera podríamos definirlo brevemente con cuatro rasgos: Caeiro (1889-1915). Vive en el Ribatejo. Huérfano de padres, no fue a la escuela, es un sabio como Sócrates, autodidacta, no tiene ideas, tiene vida. Lanza al aire sus pensamientos y sus discípulos -Reis, Campos, el propio Pessoa-las recogen. Era frágil, aunque no lo parecía y su mirada era azul. Murió de tuberculosis. Caeiro, en suma, habla porque hablar es lo propio del hombre. No habla para nombrar, porque nombrar es dar ser a las cosas y como afirma el poeta mexicano: «las palabras no son las cosas: son los puentes que tendemos entre ellas y nosotros» ( $\mathrm{Paz}$ 1985: 148). La lectura de un fragmento de Viqueira nos permitirá adentrarnos un poco más en el heterónimo:

Alberto Caeiro es el poeta que se autodenomina de la Naturaleza, una naturaleza de la realidad física de las cosas, que huye de cuanto no se pueda ver, oír, tocar, oler, gustar... por tanto, de toda abstracción. En él se encuentra un panteísmo que llega a veces al absurdo y al equívoco, lleno de contradicciones. No define las cosas, no las critica ni compara: les confiere existencia. Y ser (más que estar) es toda su definición. Su verso es libre y amplio, su lenguaje sencillo y su fuerza contundente (Viqueira 1997: 36).

Parece, por la temática de su poética, el más natural y sencillo de los heterónimos, y sin cmbargo, es el más ficticio, y en esa ficción radica la gran paradoja de su poesía, porque cl tiempo vivido, sólo por ser tiempo vivido, implica la pérdida de la inocencia y, perdida ésta, ya todo lo que se ve, se ve desde la falsedad. Por más que Pessoa quiera definir a Caciro como un ingenuo, como un naïf, el tiempo vivido le ha conferido experiencia, y la experiencia contamina. Caciro no ve el mundo con los ojos del niño, los ve con los ojos de Pessoa que ha decidido negar la metafísica, pero, aun concediendo la existencia real a Caeiro, su mirada, aunque se pretenda limpia y neutral sigue condicionada por el pensamiento que él quiere evitar, el mismo hecho de afirmar "no pienso", implica pensar. De la misma forma que negar la metafísica es construir una nueva metafísica, aunque sea la metafísica de la negación, como señala Cuervos. He ahí la gran paradoja del ribatejano, paradoja que, desde el punto de vista literario no invalida la hermosa sencillez y falsa candidez de sus versos. Cuervo vincula esta afirmación a la religión que Caeiro niega. Es cierto, como señala la autora, que en nuestra tradición occidental latina no podemos desvincularnos de la idea de Dios como el gran hacedor del mundo, después de veinte siglos de cultura judeo-cristiana, el concepto de "alma" subsiste en nuestras mentes 6 . La moral que se deriva de la religiosidad pesa como una losa, y le pesa también a Caeiro aunque quiera desapegarse de ella en poemas como el V -o el más agresivo VIII- de Guardador de Rebanhos: «Não acredito em Deus porque nunca o vi», un ateísmo de raíz sensitiva que acaba mostrándose como un ateísmo panteísta en el que, no obstante, la idea de Dios es necesaria: «Mas se Deus é as árvores e as flores [...] Para que the chamo eu Deus?» (Viqueira 1997: 258). No niega la existencia de Dios, como panteísta reconoce que dios está en todas las cosas de la naturaleza, pero decide, y he ahí, su originalidad, sustituir el nombre de Dios por en nombre de los objetos en que se manifiesta, dando a entender, por lo tanto, la innecesaria existencia del Dios Todopoderoso. El paganismo es para Caeiro la exaltación de la realidad visible percibida por los sentidos, opuesta al ideal que concebido

5.- « $\mathrm{Na}$ sua poesia, precisamente pela sua negação da metafísica, há um conteúdo metafísico muito profundo, complexo e irredutível» (Cuervo 1990: 463).

6.- En Réquiem, film de Tanner de 1998 y basado en la novela homónima de Tabucchi, se reflexiona acerca de este concepto y el lotero, supuestamente el lotero cojo que incordia a Pessoa en el Livro do desassossego, le dice que en la cultura portuguesa existe el alma, mientras que en la cultura centro-europea existe, desde los salones de Viena del $\mathrm{XIX}$, el inconsciente. 


\section{LAS MÁSCARAS DE PESSOA}

por el espíritu7. En resumen, no hay un dios oculto, es la propia apariencia de las "cosas", de la naturaleza, la que es divina.

Para llegar a este estado, Caeiro habla de un proceso de "desaprendizaje", es decir, de liberar el lastre cultural adquirido. Lo mismo que se aprende por el hecho de pertenecer a una comunidad determinada, uno puede y debe ir olvidando lo aprendido, si quiere adoptar ante el mundo que nos rodea esa actitud testimonial y descriptiva frente a las $\operatorname{cosas}^{8}$. Caeiro quiere ser el poeta de la naturaleza, y por eso trata de limpiar su conciencia de la metafísica, único modo de enfrentarse a la naturaleza desnudo, sin previos prejuicios. Volvemos, pues, a las hipótesis mencionadas al inicio del trabajo: las "cosas" deben aceptarse como son, porque nada puede ser ni suceder a como es o a cómo y cuándo ocurre. El único valor posible es el ser, hasta la idea de tiempo pondrá en entredicho cuando diga que «antes del presente, existe la realidad». Para llegar a este estado de depuración hay que pasar por la fase mencionada de desaprender, es decir, hay que iniciar el proceso contrario al aprendizaje para despojarse de todos los condicionantes culturales que pueden manipular nuestra mirada y, por tanto, nuestra relación con el mundo. El equívoco para él nace de dar prevalencia a los sentidos como método de conocimiento del mundo, desdeñando la parte humana que se caracteriza por la capacidad de razonar y que ya como tal no sólo presupone tener conciencia, sino también tener opiniones del mundo que nos envuelve?

A pesar de su aparente sencillez su poesía deviene en crítica contundente. Por una parte contra la misma poesía al negar a los falsos poetas que interpretan la naturalcza según sus necesidades sentimentales: «Li hoje quasiduas páginas / Do livro dum poeta místico, / E ri como quem tem chorado muito [...] Porque os poetas místicos dizem que as flores sentem [...] Falar da alma das pedras, das flores, dos rios, / É falar de si-próprio e dos seus falsos pensamentos» (Viqueira 1997: 280). Las flores, como dirá, no pueden sentir, porque si no, no serían flores ${ }^{10}$. Es el poeta quien inventa sentimientos a las realidades naturales, pero en verdad, sólo son los sentimientos del poeta, sobre todo del poeta romántico que es el primero en definir el mundo que lo rodea a partir de su propio estado de ánimo.

Por otra, es crítica cuando niega los postulados básicos de nuestra sociedad cultural, filosofía, moral, incluso, y esa es otra característica importante de su poética: negar todo lo que parece más humano, los sentimientos, los valores... Y esa negación también atañe a la esencia misma de su instrumento de comunicación: la palabra. Caciro duda de la palabra porque la palabra no es la cosa, el objeto existe sin necesidad de ser nombrado, por eso un "poema" debería ser apenas una enumeración de "cosas reales". El poema perfecto es una pura descripción, sin que conmueva ni sugiera ni nos lleve a pensar, todo lo contrario de lo que consiguen sus poemas -por eso son buenos-aunque en su concepción sí responden a la asepsia que Caeiro pretende. El método Caeiro consiste en ponerse frente a las cosas, mirarlas y describirlas porque las cosas se resumen en su apariencia. Hay en sus versos "cosas", pero nunca una cosa en particular, sino el objeto general como esencia genérica de lo que es. No le interesa la individualidad del ente frente a otros entes, sino la parte común que la

\footnotetext{
7.- Bréchon también sostiene esta idea, pero afirma que «en ningún lugar Caeiro se refiere explícitamente al paganismo antiguo» (Bréchon 2000: 239). Y señala que el propio Reis le llegará a reprochar que no se ha despojado totalmente de sus antiguas creencias porque las palabras que usan están cristianizadas. Y concluye: «El paganismo se opone al deísmo y al ateísmo porque no niega la dimensión divina del universo, pero transfiere lo divino desde lo lejano hasta lo cercano" (Bréchon 2000: 241).

8.- Colombini señala: «ter conciencia da tradição cultural, o que equivale a dizer, dos discursos de muitos sujeitos sobre os seus objetos, mas proceder, fingida e convictamente, como se a ignorasse» (Colombini 1990: 125).

9.- «Assim sendo, parece-me constituir um equívoco apontar em Caciro a contradição de negar o pensamento e não fazer mais que pensar» (Colombini 1990: 131).

10.- «Mas as flores, se sentissem, não eram flores, / Eram gente» (Viqueira 1997: 280).
} 


\section{AGUSTÍN FARO FORTEZA}

hace y convierte en ente. Por eso, el objeto -piedra, árbol, río- sustituye a «mármol, pino, Douro»".

Caeiro asume que el entendimiento determina la esencia de las cosas, porque determina el modo de conocerlas y reconocerlas: «O único sentido íntimo das cousas / E elas não terem sentido íntimo nenhum» (Viqueira 1997: 256), pero finge que lo ignora todo para poder convertir al objeto que mira en el centro mismo del universo que describe, de modo que el sujeto queda alejado de objeto, como si su interpretación no fuera necesaria para determinar la esencia de las cosas. Puede decirse de Caeiro que es el suprapoeta porque rompe con toda la tradición poética anterior (Campos, por cjemplo, no rompe, porque alguno de sus poemas son todavía románticos, y Reis toma modelo la antigüedad clásica). Caeiro crea la realidad, los demás la recrean, la interpretan. Pero su poética no está exenta de contradicción, pues si se conviene que en sus poemas, como señala Bréchon, existen más tautologías que metáforas, la contradicción arranca desde el inicio mismo de su poesía. El poemario se titula $O$ guardador de rebanhos, y $\sin \mathrm{embargo}$, desde $\mathrm{cl}$ primer verso señala: «Eu nunca guardei rebanhos», porque sus ovejas -así como las piedras son piedras y las estrellas, estrellas - no son ovejas, son pensamientos, él guarda pensamientos. Siendo así, toda la obra arranca de una metáfora, la misma que una y otra vez se obstina en negar tanto desde el punto de vista estilístico como temático. "Ser guardador" es para él ser poeta, y no por vocación, sino por necesidad: «Ser poeta não é uma ambição minha. / É a minha maneira de estar sozinho» (Viqueira 1997: 252). Responde, pues, su actitud con una actitud ataráxica, de mera contemplación ante el devenir, porque saber demasiado nos conduce a la tristeza y al dolor. Por eso pensar, que nos provee de conciencia, incomoda.

\section{2. Ricardo Reis}

De cultura latina por formación y helenista por vocación ${ }^{12}$, Reis, médico de profesión, culto, exiliado en Brasil, de sólida educación jesuita y quien, según Pessoa domina el lenguaje mejor que nadie, es un poeta en cicrto modo neoclásico porque hereda la tradición literaria clásica, en especial es clara y manifiesta la influencia de Horacio y sus Odas, pues la obra de Reis, unas ciento veinticinco, responde a este tipo de composición ${ }^{13}$. Y sin embargo, para Bréchon, sólo en la forma es Reis un poeta clásico: «Toma la actitud de un poeta báquico [...] Pero todo ello es meramente exterior. No hay nada dionisíaco en su poesía cerebral y sofisticada, nada carnal ni sensual, sino sólo una elegante y exigente meditación sobre el destino» (Bréchon 2000: 244)14.

Importante apurar cada instante de vida porque es irrepetible y puede ser último, el pasado, como el futuro, no existe, sólo el presente por eso hay que agotarlo, exprimirlo hasta consumirlo, porque lo vivido sólo es ausencia de la que, ni siquiera, se debe sentir melancolía, «la memoria es una fantasmagoría» (Bréchon 2000: 251). Por eso no hay que regresar al pasado, el poeta necesita el presente porque sólo en el presente se puede cumplir el destino que cada uno de nosotros

11.- Salvo menciones esporádicas como la del poema XX en la que opone «O Tejo ao rio da sua aldea» para ratificar que el río de su aldea es puro, como su idea del mundo, pues no posee connotaciones. $O$ la mención a unos árboles determinados, precisamente, para reforzar la idea genérica: «e um sobreiro não ter nascido pinheiro ou carvalho» (Viqueira 1997: 310).

12.- Elia, con gran criterio, busca los orígenes de Reis en la infancia de Durban mencionando la rigurosidad de los estudios latinos en aquella high school y, muy especialmente, la importancia de W. H. Nichols, un competente latinista que influyo notablemente en la formación de Pessoa.

13.- El número oscila según el autor. Lo cierto es que en vida de Pessoa fueron publicadas veintiocho, veinte en el número uno de Athena y ocho más en diferentes números de Presença.

14.- Elia, citando Prado Coelho, dice: «Horácio pôs na poesia muito da sua humana experiência: bebeu o vinho que cantou, teve amores com as mulheres a quem se dirigiu, o campo é para ele afectivamente o seu domínio da Sabina, invocou deuses $\mathrm{em}$ que ainda se acreditava. Em Reis, poeta derivado, tudo isso é divertimento estético ou figuração simbólica, horacianismo intencional» (Elia 1990: 367). 


\section{LAS MÁSCARAS DE PESSOA}

tenemos previsto: «Se recordo quem fui, outrem me vejo [...] Quem fui é alguém que amo / Porem somente en sonho» (Viqueira 1997: 66), y «Somos quem somos, e quem fomos foi / Coisa vista por dentro» (Viqueira 1997: 68). Esta concepción de la "vida", de su poética, se manifiesta en dos temas supuestamente opuestos: el carpe diem de raíz epicúrea-aprovecha el instante porque la vida es fugaz- y un estoicismo que lleva al poeta a la resignación, a aceptar la vida como nos llega. No hay rebeldía ante la fugacidad, sino una sumisa aceptación al Destino, porque el Destino es el rector último de los designios del Hombre. Y entre el hombre y el destino, los dioses: «Só esta liberdade nos concedem / Os deuses: submetermo-nos». Unos dioses paganos que también se hallan sometidos a la fuerza del Destino ${ }^{15}$. Ante tanta y tan superior fuerza el hombre sólo puede tratar de agotar el instante que se le ha concedido, aunque sosegadamente: «Mas decorrê-la, / Tranquilos, pácidos» ${ }^{16} ;$ «Mais vale saber passar silenciosamente / E sem desassossegos grandes» ${ }^{17}$. Esa idea del sosiego, de la calma se repite con frecuencia en sus versos y el propio Pessoa la señala como una de las ideas principales de Caeiro: «Buscando el mínimo de dolor o (...), el hombre debe procurar sobre todo la calma, la tranquilidad, absteniéndose del esfuerzo y de la actividad inútil" [...] La obra de Ricardo Reis, profundamente triste, es un esfuerzo lúcido y disciplinado para lograr una cierta calma» (apud Molina 1999: 13).

Volviendo a esa aparente contrariedad de los temas fundamentales de la poesía de Reis, en palabras de Bréchon: «La divisa del poeta de las odas es tanto el Sustine et abstine de los estoicos como el Carpe diem de Horacio y los epicúrcos» (Bréchon 2000: 246), hay que señalar que Sílvio Elia, a partir de la tesis citada en nota de Prado Coelho acerca de la impostura de Reis frente a una realidad que desconoce porque no ha vivido, propone una tercera temática, o mejor una solución que conjugue lo epicúreo y lo estoico. Habla, entonces, de «na beleza pela beleza, na beleza como puro jogo das formas» (Elia 1990: 366) y apuesta por una visión apolínca de la vida, es decir, la belleza es en sí misma un objeto y un objetivo: «A síntese superior, por tanto, entre a "brevidade da vida" e a "aura mediocritas" está nesse culto apolíneo da forma” (Elia 1990: 367) y cjemplifica con los siguientes versos: «E a beleza, incriável por meu sestro, / Eu goze externa e dada, repetida / Em meus passivos olhos; / Lagos que a morte seca».

Elemento de extrema importancia en su poética es la idea de la nada: «Nada fica de nada. Nada somos. [...] Cadáveres adiados que procriam [...] Somos contos contando contos, nada» (Viqueira 1997: 78). Esta idea del nihilismo, casi absoluto, conjuga perfectamente los temas aducidos. No somos no porque no existamos, sino porque, como decía Quevedo: «Caminar es breve jornada, Lico». La vida es un plazo con caducidad, es un tiempo limitado del que ni siquiera podemos prever el instante final. Esa fugacidad, el tempus fugit, lógicamente, es otro bastión de su obra, nos reduce a este pasar instantáneo y momentáneo de la vida. Esta concepción deriva en otra de las características propias de la literatura de aquel tiempo, la revitalización del concepto de ataraxia, es decir, entender la vida como un mero fluir ante el que no queda más remedio que aceptarlo tan como va viniendo, es inútil la acción porque todo va a suceder con independencia de nosotros: «Não há tristezas / Nem alegrias / Na nossa vida ${ }^{18}$; «E vivamos assim, / Buscando o mínimo de dor ou gozo, / Bebendo a goles os instantes frescos, / Translúcidos como água» ${ }^{19}$, ataraxia ésta que, como toda su poesía no puede desembarazarse del epicureísmo, o del estoicismo, como en el siguiente ejemplo, en que la renuncia y la contemplación han de llevar al éxtasis al sujeto: «Senta-te ao sol. Abdica / E sê rei de ti

15.- «Introduz-se aquí um novo personagem de grande importância para o paganismo (artificioso) de Ricardo Reis: os deuses. Éstão eles encima da Verdade, más também não gozam de plena liberdade. Acima dos deuses está o Destino, Fatum, Moira» (Elia 1990: 353).

16.- «Mestre são plácidas...»

17.- «Vem sentar-te comigo, Lídia...»

18. - «Mestre, são plácidas...»

19.- «Só o ter flores pela vista fora» 


\section{AGUSTÍN FARO FORTEZA}

próprio» ${ }^{20}$. Es, pues, importante para Reis «no provocar al destino» (Bréchon 2000: 252), llevar una vida discreta en la que según la regla ataráxica uno no debe esperar nada, ni siquiera en el amor, un amor, lógicamente impostado, concebido como un juego, como un complemento a la fugacidad de la vida, a la necesidad de apurar el instante: «Como se cada beijo / Fora de despedida, / Minha Cloe, beijemo-nos, amando" antes de que la barca de la muerte nos alcance como pasajeros. Y de nuevo, el pez que se muerde la cola, concepto de nada, aceptación resignada, porque la felicidad nos viene dada. No es más feliz quien busca para encontrar, sino quien se despreocupa y halla: «Aos que a felicidade / É sol virá a noite. / Mas ao que nada 'spera / Tudo que vem é grato»"21.

Viqueira señala que Reis vive fuera de su tiempo, pero no en el pasado, sino en la intemporalidad. «Reis es el poeta pagano, o mejor, pseudo-pagano. A través de unas odas de factura horaciana, plenas de ecos clásicos, nos descuelga toda su filosofía epicureísta filtrada por el espíritu moderno, su deseo de absentismo del vivir - que es dolor- aun a costa del dolor de no hacer nada y ver cómo todo pasa, se aleja y se pierde» (Viqueira 1997: 36). Que Reis es un pagano se advierte en una primera lectura, pues los antiguos dioses greco-romanos llenan sus versos, pero ¿pseudo-pagano? Quizá haya que entender en su paganismo la inclusión de la religión cristiana ${ }^{22}$. Lógicamente a un pagano como Reis no le interesa la figura de Cristo, lo acepta como un dios más, si acaso como el último, pero no distinto de los otros. Los dioses le son indiferentes, del mismo modo que los hombres son indiferentes para los dioses. Si utiliza los dioses, ya hemos visto que ni siquiera ellos tienen el privilegio de lo absoluto pues el Fatum está sobre ellos, lo hace porque a través de cllos muestra los valores decadentes tan propios de las temáticas que trata.

Un elemento importante para comprender su obra es atender al metro en que está escrita. Es evidente que si recupera la "oda horaciana" debe hacerlo respetando los parámetros propios de poesía latina. Y sin embargo, la lengua portuguesa no puede ser medida con pies rítmicos. Azevedo señala al respecto: «O assunto, absorvido, pelo tema, vem da filosofia pagã, deixando-se filtrar pela emoção, antes de consubstanciar-se nos perfeitos decassílabos e nos perfeitos hexassílabos das estrofes dísticas» (Azcvedo 1990: 492). Esta perfecta adecuación ha desembocado en potenciar la nitidez y la perfección del verso de Reis utilizando términos propios de la lingüística, en concreto, la ideas de Hjemlsev sobre la forma del contenido y la expresión. Así, el tema pagano, forma del contenido, halla su justa medida en la expresión empleada, forma de la expresión. Esta afirmación no es gratuita puesto que la perfección del metro, la ecuanimidad de lo dicho, la adecuación de contenido y continente conllevan la perfección de lo clásico, y Reis pretende, ante todo, ser un clásico: «tudo harmonia, equilíbrio, medida» ${ }^{23}$. Si hemos visto que en Caeiro la sensación lo preside todo, y aunque no se pretenda la emoción, sus descripciones sensitivas emocionan; Reis procura la emoción a través del pensamiento: «O pensamento (assunto) é anterior à palavra $[\ldots]$ O verso se ajustará ao pensamento [...] Se o pensamento for alto e régio, como súditos, o ritmo e a frase irão ao seu encontro. Tudo harmonia, cquilíbrio, medida» (Azevedo 1990: 486) 24 $^{24}$ Directamente de Reis:

20.- «Não tenhas nada nas mãos»

21.- Baroja, a través de Andrés Hurtado, El árbol de la ciencia, ejemplifica con brillantez el prototipo del hombre ataráxico; o también lo hallamos en Azorín - personaje - de La voluntad. "Quero ignorado, e calmo».

22.- Hay que recordar que Reis es muy crítico con el maestro Caciro cuando le reprocha no haberse despojado totalmente de su moral judeo-cristiana.

23. - Por tanto para Ricardo Reis «um poema é a projeção de uma idéia em palavras através da emoção» (Azevedo 1990: 487).

24.- Este concepto de poesía de altura para definir el verso de Reis, lo pone Pessoa en boca de Campos, quien halaga la "altura" del verso de Reis. "Que él ponga en la mente activa (altiva) el esfuerzo solo de la "altura" (sea esta lo que sea), lo admito, aunque me parezca rigurosa una poesía limitada al escaso espacio propio de las cumbres» (apud Molina 1999: 14). Para aclarar el concepto de "altura" me remito a una definición del propio Reis: "Cuando el pensamiento del poeta es alto, esto es, formado por una idea que produce una emoción...» (apud Molina 1999: 15). Incluso lo hallamos como poema: «Ponho na altiva mente o fixo esforço / Da altura [...] Que, quando é alto e régio o pensamento / Súbdita a frase o busca». 


\section{LAS MÁSCARAS DE PESSOA}

Cuanto más fría la poesía, más verdadera: la emoción no debe entrar en la poesía sino como elemento dispositivo del ritmo, que es la supervivencia lejana de la música en el verso. Y ese ritmo, cuando es perfecto, debe surgir antes de la idea que de la palabra. Una idea perfectamente concebida es rítmica en sí misma; las palabras donde perfectamente se diga no tienen poder para abatirla. Pueden ser duras y frías, no importa; son las únicas y por ende las mejores. Y, siendo las mejores, son las más hermosas (apud Molina 1999: 14).

En este punto, Reis se distancia totalmente del maestro, pues si para Caeiro el poema perfecto cra aquel que estuviera totalmente desprovisto de emoción y de pensamiento, Reis dice: «Un poema es la proyección de una idea en palabras a través de la emoción. La emoción no es la base de la poesía, es tan sólo el medio del que la idea se sirve para reducirse a palabras» (apud Molina 1999: 14).

En definitiva, hallemos todo Reis condensado en estos versos: "Cumpramos o que somos. I Nada mais nos é dado» ${ }^{25}$.

\section{3. Álvaro de Campos}

Álvaro de Campos es la gran contradicción de Pessoa, el heterónimo más próximo y a la vez más lejano del hombre Pessoa. Que cstá a gran distancia del hombre se manifiesta en las características del heterónimo, Campos es ingeniero naval, se ha formado en Escocia, ha viajado pro Oriente, de donde trajo el poema "Opiarium", y es, como ahora comentaremos, un gran extrovertido. Comparte con el hombre el gusto amargo de la existencia, el lúcido pesimismo que se forja brillante ante la página escrita y, sin embargo, Álvaro de Campos es un hombre decidido, capaz de asumir los compromisos que el ortónimo no es capaz de defender ${ }^{26}$. La voz de Campos se alza contra $\mathrm{el} \mathrm{mundo} \mathrm{en} \mathrm{un} \mathrm{tono} \mathrm{que} \mathrm{al} \mathrm{reservado} \mathrm{y} \mathrm{tímido} \mathrm{Pessoa} \mathrm{nunca} \mathrm{se} \mathrm{le} \mathrm{hubiera} \mathrm{ocurrido.}$ Pcro no es Campos un arma de Pessoa para expresar su ira contra el mundo, Campos es el más hijo de su tiempo de todos los heterónimos porque es el futurista, el que se adhiere sin vacilar a las nuevas corrientes literarias que aparecen a principios de siglo. Campos asume también el alcoholismo de Pessoa, al heterónimo no le importa la calidad de lo que bebc. Pero es a través del alcoholismo que Campos logra vencer sus inhibiciones y hacer, de este modo, que las venza el propio Pessoa ${ }^{27}$. Pero, por encima de todo, la grandeza del heterónimo Campos es que sufre una evolución en su compromiso literario. El entusiasta de la primera época, el hombre que confía sobre todo en el poder de la máquina, deja paso al vacilante, al desengañado que trasluce con profunda voz melancólica todo el desencanto que ha acaudalado ${ }^{28}$. Penha Coelho señala: «Álvaro de Campos, em certa altura de seu percurso poético, passa a ignorar aquilo que considerou como uma das mais deslumbrantes aquisições de seu tempo, das quais a máquina seria o emblema de maior representatividade. Inicia-se, então, a viagem para dentro. O poeta torna-se introspectivo» (Penha 1990: 201). En este momento, la afirmación de Octavio Paz, «Álvaro de Campos es un

25.- "Cada um cumpre o destino...»

26.- «Campos produce muchas veces la impresión de ser un doble de Pessoa libre de muchas de sus inhibiciones, pero se diferencia, no obstante, de él, no sólo por us espontaneidad, sino también por su confesada experiencia sexual» (Crespo 1988: 152).

27.- «Es un ser tan dividido, tan disperso, la bebida permite quizá restablecer una unidad, hacer de la consciencia una esfera giratoria, viviente; aún más: fundir en una sola impresión central las innumerables sensaciones entre las cuales se dispersa y a las que "nunca sabe poner fin"» (Brechon 2000: 125). Quizá, a consecuencia de esta influencia, el heterónimo interfiera en la vida del hombre. La propia Ophélia Queiroz se lamentará de la amarga intromisión de Campos en su relación puesto que el heterónimo, con su grosería, desmonta toda la dulzura que a veces partía de Pessoa, una falta de control que bien pudiera derivarse directamente de las crisis alcohólicas.

28.- «En 1924 el Campos poeta atraviesa un eclipse poético. El Campos que encontramos en Athena es el de Portugal Futurista y el de Ultimátum. No es el discípulo optimista de Whitman, sino el que, dentro de la "camarilla", asume el papel poco simpático del espíritu que niega» (Brechon 2000: 426). 
futurista integral, pero Fernando Pessoa sigue siendo un poeta "paulista" (Paz 1985: 138), se derrumba. La contradicción referida se sostiene en la primera época, pero en sus últimos poemas Campos es la expresión de la desgana de la vida, de ese "desasosiego" que, no muy lejos de esos postulados de fondo, escribirá Bernardo Soares. "Tabacaria" es uno de los poemas que mejor dan testimonio de la aguda consciencia de su fracaso literario, por un lado, y del atroz sufrimiento que le acompañó durante toda su vida. Pessoa hace decir a Campos que «todos tenemos dos vidas: la verdadera, esa que soñamos en la infancia, y la falsa, esa que vivimos en convivencia con los otros» (Brechon 2000: 427) 29 : «Porque é possível fazer a realidade de tudo isso sem fazer nada disso». "Tabacaria", muestra plenamente al Pessoa derrotado $-«$ Falhei em tudo»- y trasluce con gran brillantez el debate interior que en ese tiempo lo consume: la consciencia de que su búsqueda es vana porque nada puede escapar a la realidad concreta de su existencia vivida. "Não sou nada» afirma el poeta en el primer verso negando la realidad de su propia existencia, una realidad que tampoco posee futuro - «nunca serei nada»- por la propia imposibilidad que está condicionando el presente interno, consciente, del poeta: «Não posso querer ser nada». Una incapacidad que se desmonta y nos sorprende en el cuarto verso que parece negar todo lo hasta entonces afirmado: «À parte isso, tenho em mim todos os sonhos do mundo». Pero para interpretar esta afirmación es necesario deslindar entre lo real objetivo y la auténtica realidad que es la que el poeta construye desde el sueño, incluso, un espacio físico como el cstanco, y por tanto manifiestamente real, cae, por esa misma perplejidad que acucia al poeta, dentro de los límites de la duda: «a lealdade que devo / À Tabacaria do outro lado da rua, como coisa real por fora, / E à sensação de que tudo é sonho, como coisa real por dentro». El tono directo de "Tabacaria" agudiza la visión que tiene el poeta de la liviandad del ser humano como ente individual, del poco peso del hombre frente al peso conjunto de la vida social. El pocta sólo es uno frente al resto, él resta aislado en la soledad de su alcoba (una entre los millones que hay en el mundo) y sólo a través de las ventanas - «Chego à janela e vejo a rua com uma nitidez absoluta»-puede tomar conciencia con el mundo social. A partir de ahí se desarrolla la antítesis mundo personal, mundo social, enfocado, como también aparecerá en el Libro del desasosiego, desde la óptica de triunfo póstumo: «E há tantos que pensam ser a mesma coisa que não pode haver tantos!». El sueño queda como el refugio, como la expresión del ataráxico a quien la vida lo vence: «Tenho sonhado mais que o que Napoleão fez [...] Mas sou, e talvez serei sempre, o da mansarda [...] Serei sempre o que nasceu para isso", versos que expresan con violento dolor el choque brutal entre el deseo y la realidad-extraordinariamente expresado en el coloquialismo «el que nació para eso»-, el mundo creado a imagen y semejanza frente al mundo de todos en que físicamente nos desenvolvemos.

Paz sostiene que "Tabacaria" es el poema del rencuentro del propio Pessoa consigo mismo. Argumentos no faltan pues tras las palabras se descubre al hombre-«Conheceram-me logo por quem não era e não desmenti, e perdi-me [...] Deitei fora a máscara e dormi no vestiário». Pero es más, como se ha dicho, la confesión de la derrota de la inutilidad de la vida pública vivida, porque por debajo de lo público habita la esfera de lo privado, el interior del cuarto en el que da lo mismo quién se es porque uno es sólo él mismo: «E se soubessem quem é o que saberiam?». Una confesión que trasciende a lo individual cuando aparece el dueño del estanco y, por comparación, ya no es el individuo el que es puesto en tela de juicio, sino todo el universo que también está llamado a desaparecer, todo resulta inútil y estúpido porque nada es trascendente, porque todo se agota y cualquier "cosa" vale para sustituir a esa misma "cosa": «Morrerá depois o planeta girante em que tudo isto se deu [...] Sempre o impossível tão estúpido como o real [...] Sempre isto ou sempre outra coisa ou nem uma coisa nem outra ${ }^{30}$. Pero al final, la metafísica, que ha sido la

29. - La idea de que la vida soñada es la única forma de vida posible, la auténtica vida, será analizada en la obra de Soares, ya que muchos de sus escritos se refieren a este tema.

30.- Con respecto a estos versos y a la idea de la muerte en Campos: «a morte como estágio último e inarredável do seu destino, após o qual inexiste qualquer movimento da transcendendência, mas sim o do mais completo aniquilamento» (Penha 1990: 206). 


\section{LAS MÁSCARAS DE PESSOA}

base de especulación del poeta en el poema, se rinde ante la evidencia de la realidad física y la presencia de un conocido, o Esteves, - que para Paz no es más que el monigote de todo aquello que Pessoa/Campos desprecia- representa la derrota de lo personal ante lo social, aunque, como último recurso: «E vou tencionar escrever cstes versos em que digo o contrário».

Una síntesis de las afirmaciones de Brechon nos permite acercarnos a la auténtica realidad de Campos. Campos es un sismógrafo psíquico que nos permite, al exagerarlos, evaluar los cambios de humor, los impulsos entusiastas y las crisis depresivas de Pessoa; sabemos que su registro es muy amplio, y va desde la alegría orgiástica hasta la angustia metafísica, del fervor desbordante a la ternura algo llorona. Las circunstancias de 1917 «le darán ocasión de desfogarse una última vez y escribir y publicar su más violento texto, Ultimátum. Después volverá a su silencio durante seis años. Luego volveremos a recuperarlo, pero quebrado, por la dificultad de ser, y es un Campos derrotado que escribirá, hacia los cuarenta años, sus poemas más conmovedores, entre ellos "Estanco"» (Brechon 2000: 346). Y Octavio Paz: «Campos vive en el instante, cosmopolita, desterrado, no tiene un lugar en el mundo. Utiliza el verso libre, no elude los prosaísmos. Es pesimista, ama lo concreto, desprecia lo externo a él [...] Campos, el dandy vagabundo, es lo que hubiera podido ser y no fue» (Paz 1985: 149). De ambas definiciones puede inferirse esa estrecha unión entre el hombre y el heterónimo como deseo de ser, quizá el mejor modo de "soñarse" que el poeta puede poseer.

Vamos, a continuación, a ahondar en el heterónimo a través de algunos de sus poemas más importantes.

«De la máquina de escribir - dirá Pessoa en la carta a Casais Monteiro- sin interrupción, a chorro, salió la Ode Triunfal de Álvaro de Campos: la oda de este nombre y el hombre con el nombre que llevà). Y dirá también de ambas odas: «Hasta hoy... sólo ha habido tras verdaderas manifestaciones del arte no aristotélico. La primera está en los asombrosos poemas de Walt Whitman; la segunda, en los poemas más que asombrosos de mi maestro Caciro; la tercera, en las odas -"Oda triunfal" y "Oda marítima"que publiqué en Orpheu». En "Ode triunfal" Campos se presenta plenamente como "el cantor de la era industrial, de la violencia de la vida y del expresionismo más concreto" (Brechon 2000: 257), "cuya influencia futurista, una novedad, se hace sentir a la hora de escoger el tema (la moderna civilización comercial e industrial), en el léxico técnico-científico, en la libertad métrica y estrófica, en la presencia de interjecciones y onomatopeyas, cn el panteísmo orgiástico y mecanicista que domina el poema» (Gavilanes 2000: 519). Citas éstas que definen bien al poema y al heterónimo y que concluimos con: «La Oda Triunfal no es epicúrea ni romántica ni triunfal: es un canto de rabia y derrota. Y en esto radica su originalidad» (Paz 1985: 150). La máquina aniquila al hombre, por eso al final pierde la palabra. Campos, en realidad, critica la utopía futurista. Cuando el poeta advierte que los valores asociados al futurismo no sirven para mejorar al hombre ni en su plenitud espiritual ni siquiera como mejora de lo social, sobreviene la desilusión, a pesar de estar expresado con gran furor. Desde este postulado del desencanto del canto a la modernidad voy a comentar el poema.

Los primeros versos son muy relevantes de la pasión que siente el poeta: escribe desde un estado de sublimación, no desde la razón sino desde la fuerza del inconsciente «Tenho febre e escrevo», y lo hace como no hubiera podido jamás hacerlo el hombre antiguo «à dolorosa luz das grandes lâmpadas eléctricas», por eso el poeta antiguo no podría comprender ni la belleza ni la grandeza -«a beleza disto totalmente desconhecida dos antigos»- que transmiten estos versos de la más pura modernidad de principios de siglo XX: "Ó rodas, ó engranagens, $r-r-r-r-r-r$ eterno!», pero en el interior de las máquinas que también son su propio interior que vive acelerado, incluso la expresión, la forma, la grafía aparece con nuevos modelos. La exaltación por la máquina, en la que también está el pasado, lleva al poeta al deseo de la fusión total: «Ser completo como uma máquina!». El poema se desarrolla como un furibundo canto de alabanza de lo moderno, ya no sólo de las máquinas, sino de la sociedad que se crea en ese tiempo: «E toda agente simplesmente elegante que passeia e se mostra [...] A maravillosa beleza das corrupções políticas [...] Amovos a todos, a tudo, como uma fera». Y de pronto ese mundo de esplendor se nos dibuja em su 


\section{AGUSTÍN FARO FORTEZA}

más abyecta realidad, y los coches se llenan de putas y los hijos roban y las niñas masturban a pederastas en las escaleras. Y puede preguntarse entonces uno, ¿dónde está el progreso? ¿En qué han mejorado las máquinas nuestra vida? ¿No era todo mejor cuando él era «outra coisa / Do que eu sou hoje?». Expresado este recuerdo de infancia ente paréntesis, como una huida a la realidad que ahora lo arrasa desde la fiebre de la modernidad. Pero el paréntesis es sólo eso, un inciso, del que el poeta escapa porque, como dice al inicio, lo único que importa es el presente, y el presente es la modernidad de la máquina: «Tudo isso apaga tudo, salvo o Momento [...] Eia todo o passado dentro do presente! / Eia todo o futuro ja dentro de nós!».

Se puede emparentar "Ode Marítima" con "Ode Triunfal" puesto que ambas parten de dos postulados básicos. Son un canto a la violencia, más desmedida en la primera y a la modernidad más obvio en la segunda. El vértigo de la velocidad que conduce a la convulsión ya ha sido comentado. La idea de modernidad en la "Ode Marítima" es clara desde el principio, pues se canta el mar no desde su inmensidad, sino desde el muelle (y sólo desde el Muelle de Lisboa que mitifica en el poema "Não é ponte entre qualquer cais e O Cais") un lugar artificial creado por la mano del hombre y que, lógicamente condiciona la visión que se posee «Sòzinho, no cais deserto, a esta manhã de Verão / Olho pró lado da barra»" ${ }^{31}$. Y lo que busca no es la braveza del mar, ni el encanto del reflejo de la luz, sobre la superficie, busca lo artificial, su vista se dirige hacia «um paquete entrando», "erguem-se velas, avamçam rebocadores». La belleza está en las máquinas que resultan auténticos elementos estéticos del paisaje portuario: «num ruído de guindastes [...] comboios de mercadorias [...] Em divino êxtase revelador». Y desde la asunción del trasatlántico como parte misma del alma - «mas a minh'alma está com o que vejo menos»-, doble signo de distancia porque es el bareo que navega más lejos y porque en el presente de su mirada es el más alejado a esta, cuando el poeta abstrae la realidad para internarse en su espíritu, a veces con la melancolía de lo efímero, de lo que viene y se va «Todo o atracar, todo o largar de navio [...] Ameaçador de significações metafísicas»; pero sobre todo, a partir de que el barco zarpe, el motivo que dará a su palabra rienda suelta para evocar e invocar la angustia y los sentimientos que se revelan a través del otro yo que hila el poema: «Vem-me, não sei porquê, uma angústia recente $[\ldots]$ E me envolve como uma recordação duma outra Pessoa / Que fosse misteriosamente minha». Es revelante en el poema que a pesar de la exaltación a lo moderno $-« \mathrm{E}$ eu, que amo a civilização moderna, eu que viejo com a alma as máquinas / Eu o engenheiro, eu o civilizado, cu o educado no estrangeiro» - todo se contempla con los ojos de la añoranza melancólica, con $a$ saudade: «Gostaria de ter outra vez ao pé da minha vista só veleiros e barcos de madeira, / De não saber doutra vida marítima que a antiga vida dos mares». El alma ya está preparada para asumir el gozo de la vida marítima, para dejarse llevar por el mar hasta el fondo de los pensamientos y los sentimientos del hombre: «Toda a vida marítima! tudo na vida marítima!». El pocta se ha embebido de vida marítima y necesita hallar cauce para la expresión de una necesidad urgente: «Fornecei-me metáforas, imagens, literatura / Porque em real verdade, a sério, literalmente, / Minhas sensações são um barco de quilha pró ar». Y desde ese punto cuando no queda más cauce para la expresión que el mar, el poema deriva hacia una descripción subjetiva de sus evocaciones, que no olvidan la infancia, transformadas en auténticas pesadillas cuando se muestra el lado más cruel y violento de ese yo que se ha apropiado del viaje iniciado. Desde aquí se describe con precisión el malestar físico y metafísico que concluirá con la justificación de su elección de la vida sedentaria. Toda la parte central se articula en torno a la imaginería de los piratas, pero para poner de relieve sus actitudes sádico-masoquistas. Esta violencia sirve para desvelar lo tanta veces dicho de Campos con respecto a Pessoa, es el lado oscuro, violento, aquel que dice lo que nunca

\footnotetext{
31.- Parecen insuficientes los puntos de contacto entre Réquiem de Alain Tanner y pasajes del Livro do desassossego. Es por ello que tan sólo voy a citar algunas escenas que parecen directamente tomadas, como cl inicio del film que se ajusta perfectamente al inicio de "Ode Marítime" ya que arranca desde la soledad de un personaje que en una calurosa mañana de verano espera a Pessoa. Quizá el trabajo relevante en cuanto a literatura comparada haya que buscarlo con la novela homónima de Tabucchi.
} 


\section{LAS MÁSCARAS DE PESSOA}

Pessoa diría: «Quero encontrar [...] / Perder convosco a noção da moral [...] despir de mim ... o meu traje de civilizado, a minha blandura de acções / Meu medo inato das cadeias». Violencia que se funde con el mar y del mar parece venir y al mar parece dirigirse, como el primer barco que partió hacia el océano desde el muelle: «Fazei o que quiserdes de mim, logo que seja nos mares [...] Arranquem-me a pele, preguem-a às quilhas». En la mencionada parte central, la que refiere las hazañas de los piratas, es el momento en que la crueldad alcanza su momento más extremo, quizá por eso este fragmento incluye las onomatopeyas que son: «Este grito, que identifica el orgasmo sadomasoquista con el universo marino, maca el clímax del poema. Durante un momento (unos quince versos), el poeta, atontado, sólo puede proferir onomatopeyas. Y es la brutal caída de tensión, que lo devuelve a su estado, a su naturaleza, a su sentimentalidad y a su nostalgia» (Brechon 2000: 267). Tras la crueldad, la infancia viene a calmar los ánimos del poeta: «E a minha infancia feliz acorda, como uma lágrima, em mim, / O meu passado resurge [...] Ah, como pude eu pensar, sonhar aquelas coisas? Que longe estou do que fui há uns momentos!». La ternura, la nostalgia, la protección es lo que aflora de su pasado: «E a paz do luar esparso nas águas!... / Minha velha tia, que me amava». La saudade mezclada con «a minha imaginação higiénica, forte, prática» dan como resultado la vuelta al presente, al sosiego que se tienc desde cl muelle, aunque la existencia de la violenta vida imaginada provoca que la vida cotidiana sea más difícil de vivir por su frustrante monotonía. Y sin embargo, hasta se advierte cierto aire poético cuando describe la realidad del mundo que lo rodea: «Venham dizer-me que não há poesia no comércio, nos escritórios! [...] Porque as facturas e as cartas comerciais são o princípio da história». Con esta sensación de dualidad entre lo real y lo soñado, se despide del otro yo que le inspiró la vida cantada en la oda: «Boa viagem, meu pobre amigo casual que me fizeste o favor / De levar contigo a febre e a tristeza dos meus sonhos».

Opiário, no hay que olvidarlo, es un poema que Campos se trae de su viaje por Oriente y, por tanto, anterior a su obra, lo que, es evidente, debería traslucirse en su estilo. Dice Pessoa: «Entonces se me ocurrió la idea, que consulté con Sá-Carneiro - a quien se dedica el poema-, de escribir un poema "antiguo" de Álvaro de Campos - un poema que mostraba cómo podía ser Álvaro de Campos antes de conocer a Caeiro y de caer bajo su influencia. Así es como escribí "Opiário", en el cual intenté mostrar todas las tendencias latentes en Álvaro de Campos, tal como se revelarían después, pero sin que se descubriese la menor huella de su contacto con el maestro Caciro. Es, de todos mis poemas, el que más me costó escribir, debido al doble poder de despersonalización que debí poner en juego...». De modo que este poema es un falso Campos, la máscara de una máscara. Es la queja de un distinguido trotamundos nihilista que se droga $-\ll \mathrm{E}$ eu vou buscar ao ópio que consola"- por no haber encontrado sentido a la vida - «É antes do ópio que a minh'alma é doente»-. Pero ni el ópio ni el conocimiento de nuevas gentes le procura la paz. que ha ido a buscar a Oriente: «Falo com alemães, suecos e ingleses / E a minha mágoa de viver persiste». De Campos existe la provocación «Só para dar que falar de mima os maos»; el recurso de la droga frente a la sociedad estable, pero le falta el punto de exaltación que posee el primer Campos. Hay más semejanza con el segundo Campos, con el hombre desencantado de la vida, «E afinal o que quero é fé, é calma / E não ter estas sensações confusas / Deus que acab com isto!», pues es el desencanto lo que preside el poema y lo que se toma como justificación del viaje a Oriente y del refugio en el opio.

"Lisbon revisited" es un título que responde a dos poemas diferentes, unidos por la ficcionalidad de que el escritor regresa a Lisboa. Pero mientras el primero, "Lisbon revisited (1923)" es una queja en la que se trasluce la vida del propio Pessoa; el segundo "Lisbon revisited (1926)", sin olvidar ese rencuentro con la ciudad - «Outra vez te revejo / Lisboa e Tejo e tudo» (1926), "Ó macio Tejo ancestral e mudo» (1923)- ahonda más en la fragmentación del yo poético que acaba diluido en el pasado: «Mas sou cu o mesmo que aqui vivi, e aqui voltei [...] Outra vez te revejo / Mas, ai, a mim não me revejo» y el desencanto de los años que se concretará como en "Tabacaria" 


\section{AGUSTÍN FARO FORTEZA}

en el tedio: «E um tédio que é até do tédio arroja-me a praia»" ${ }^{32}$. Crespo considera que "Lisbon revisited (1923)" es uno de los ejemplos más claros de lo que él denomina drama em gente, un tipo de composición en que los diversos heterónimos se confunden con el ortónimo hasta el punto de que es difícil delimitar la aportación de cada uno de ellos. Y prosigue: «la métrica y el estilo impulsivo son muy de Campos, pero, en cambio, las referencias a una experiencia inmediata que parece ser la de Fernando" (Crespo 1988: 211), y entiende por "referencias inmediatas" la renuncia al matrimonio con Ofelia y los consejos de su madre. Sin embargo, es (1926) el que nos parece un claro ejemplo del drama en gente, pues en él se plantea desde un punto de vista literario la existencia de sus heterónimos: «Partiu-se o espelho mágico em que me revia idêntico, / E em cada fragmento fatídico vejo só um bocado de mim». Mientras que la experiencia vivida aparece con gran claridad en la queja de (1923): «Queriam-me casado, fútil, cuotidiano e tributável?».

Hemos hablado del Campos desengañado, y ése sí se manifiesta de modo explícito y violento en ambos poemas. Campos quiere ante todo su soledad, vivir su vida sin condicionamientos, como mejor le plazca, por eso: «Não, não quero nada. / Já disse que não quero nada [...] Não me macem, por amor de Deus! [...] Vão para o diabo sem mim [...] Deixem-me em paz!» (1923); «Nada me prende a nada» (1926). En este último, a veces, el tono se acerca al desencanto de Soares y el sueño, como auténtica vida vivida, se manifiesta en toda su intensidad: «E, no fundo do meu espírito, onde sonho o que sonhei» y sustituye el tono de queja por una melancolía que sólo tiene como salida el desencanto absoluto: "Outra vez te revejo, / com o coração mais longínquo, a lama menos minha».

Como conclusión sirvan las palabras de Viqueira: «Álvaro de Campos es el poeta existencialista, verdadero precursor de la poesía de nuestro tiempo, el metafísico, el de la trascendencia resignada. Con un verso libre y extenso, a veces pleno de imágenes sorprendentes y de caprichos sintácticos en los que abundan toda suerte de recursos y licencias poéticas, Campos es la faceta más humana, más emotiva de Pessoa. A él compete el recuerdo de la vida pasada y perdida, el quejido por la abulia, la impotencia y la incapacidad por hallar la felicidad, o cuando menos un eco de ella; el que escribe el mundo y la vida como deberían ser pero que se rinde a la evidencia de que no lo son, resignado las más de las veces, impotente siempre» (Viqueira 1997: 36)

\section{REFERENCIAS BIBLIOGRÁFICAS}

AA. VV. (1990): Actas do IV Congresso Internacional de Estudos Pessoanos, Fundação Eng. António de Almeida, Porto.

ARRIBAT-PAYCHÈRE, E. (1990): “As quedas e os caminhos para o cais absoluto na obra poética de Álvaro de Campos" en Actas do IV Congresso...

AZEVEDO FILHO. L. (1990): "Sobre as odes de Ricardo Reis" en Actas do IV Congresso...

BRÉCHON, R. (2000): Extraño extranjero: una biografía de Fernando Pessoa, Alianza Editorial, Madrid.

COLOMBINI, D. (1990): "Pessoa e metafísica" en Actas do IV Congresso...

CRESPO, A. (1988): La vida plural de Fernando Pessoa, Seix Barral, Barcelona.

CUERVO HEWITT, J. (1990): "Metafísica da negação: A negação metafísica na poesia de Alberto Caeiro" en Actas do IV Congresso...

32.- Brechon señala que los poemas evocan el regreso del adolescente a su ciudad (1905), de ahí el título en inglés, lengua de ese tiempo. El cielo, el Tajo, serán los indicios y motivos que lleven a «muchos de sus sentimientos habituales pasan por este lamento: la perpetua confrontación con el niño que ha sido, el recuerdo del vacío que le ha dejado la pérdida de su madre, la existencia de Lisboa como un sueño, como ciudad fantasmal y a la vez familiar; la soledad, la tristeza, la condición de extranjero, la inutilidad de todo, etc.» (Brechon 2000: 93). 


\section{LAS MÁSCARAS DE PESSOA}

D’ALGE, C. (1990): "Ressonância da Ode Triunfal, de Álvaro de Campos, no poema Táxi, de Adriano Espínola" en Actas do IV Congresso...

ELIA, S. (1990): “O Horaciano Ricardo Reis" en Actas do IV Congresso...

FERNANDES, J. (1990): “A tradição greco-latina nas odes de Ricardo Reis (uma análise quantitativa)" en Actas do IV Congresso...

GAVILANES, J. L. Y APOLINÁRIO, A (2000): Historia de la literatura portuguesa, Cátedra, Madrid.

LLARDENT, J. A. (1984): Fernando Pessoa: Antología de Álvaro de Campos, Editora Nacional, Madrid

MOLINA, C.A. (1999): Fernando Pessoa: Odas de Ricardo Reis, El Mundo, Madrid.

PAZ, Octavio (1985): Cuadrívio: Darío, Lopez Valarde, Pessoa, Cernuda, Barcelona, Seix Barral.

PENHA COELHO, O. (1990): "Leitura de Álvaro de Campos (Um percurso da modernidade: da euforia para a disforia)" en Actas do IV Congresso...

VIQUEIRA, M.A. (1997): Pessoa: Obra poética, Ediciones 29, Madrid. 